\title{
Litter contribution to soil organic carbon in the processes of agriculture abandon
}

\author{
A. Novara, J. Rühl, T. La Mantia, L. Gristina, S. La Bella, and T. Tuttolomondo \\ Department of Scienze Agrarie e Forestali, University of Palermo, viale delle Scienze, 90128 Palermo, Italy \\ Correspondence to: A. Novara (agata.novara@unipa.it)
}

Received: 15 January 2015 - Published in Solid Earth Discuss.: 6 February 2015

Revised: 27 March 2015 - Accepted: 1 April 2015 - Published: 24 April 2015

\begin{abstract}
The mechanisms of litter decomposition, translocation and stabilization into soil layers are fundamental processes in the functioning of the ecosystem, as they regulate the cycle of soil organic matter ( $\mathrm{SOM})$ and $\mathrm{CO}_{2}$ emission into the atmosphere. In this study the contribution of litters of different stages of Mediterranean secondary succession on carbon sequestration was investigated, analyzing the role of earthworms in the translocation of SOM into the soil profile. For this purpose the $\delta^{13} \mathrm{C}$ difference between meadow $\mathrm{C}_{4}$ $\mathrm{C}$ soil and $\mathrm{C}_{3}-\mathrm{C}$ litter was used in a field experiment. Four undisturbed litters of different stages of succession (45, 70, 100 and 120 since agriculture abandon) were collected and placed on the top of isolated $\mathrm{C} 4$ soil cores.

The litter contribution to $\mathrm{C}$ stock was affected by plant species and it increased with the age of the stage of secondary succession. One year after the litter position, the soil organic carbon increased up to $40 \%$ in comparison to soils not treated with litter after 120 years of abandon.

The new carbon derived from $\mathrm{C}_{3}$ litter was decomposed and transferred into soil profile thanks to earthworms and the leaching of dissolved organic carbon. After 1 year the carbon increase attributed to earthworm activity was 6 and $13 \%$ in the soils under litter of fields abandoned for 120 and 45 years, respectively.
\end{abstract}

\section{Introduction}

The major input of vegetative $\mathrm{C}$ to forest soil is represented by litter; hence changes in litter inputs are likely to have important consequences for soil C dynamics (Sayer et al., 2007). Generally, it has been recorded that an accumulation of litter corresponds to an increase of the carbon storage in the soil; for instance, an accumulation of litter and a consequent increase in the carbon content of the soil has been recorded following the processes of abandonment (Costa and La Mantia, 2005).

Therefore, the mechanisms of litter decomposition, translocation and stabilization into soil layers are fundamental processes in the functioning of the ecosystem as they regulate the cycle of soil organic matter (SOM), $\mathrm{CO}_{2}$ emission into the atmosphere, carbon sequestration into the soil and nutrients mineralization (Maisto et al., 2011; ParrasAlcántara et al., 2015; Smolander et al., 2008; Fioretto et al., 1998, 2005).

The decomposition of litter is affected by the quality of the residues (Smith et al., 2008), which determines different mineralization rates. Soluble substances and labile compounds of litter are rapidly degraded in the early stages of decomposition by fast-growing microorganisms that may require a high concentration of nitrogen (Swift et al., 1979). Cellulose and lignin, the most abundant components of forest litter, are decomposed slowly (Fioretto et al., 2005). Together with bacteria and fungi, invertebrates are responsible for the main functions of the soil ecosystems, including $\mathrm{C}$ cycle (Dix and Webster, 1995; Peng et al., 2015; Schimel et al., 1999). Several authors have attributed earthworms to the creation of favorable conditions for microbial activity through the fragmentation of litter and mixing of organic matter with soil mineral portion (Tiunov et al., 2001; Wurst et al., 2004).

Earthworms also affect both amount and distribution of SOM and cause an increase in the rates of SOM decomposition. Earthworms, in fact, transport large quantities of $\mathrm{C}$ from the surface of the soil to the lower horizons, effectively mixing the soil and significantly increasing both the rates of the humification trough litter fragmentation and of the overall 
decomposition (Lee, 1985; Alban and Berry, 1994; Edwards and Bohlen, 1996; Burtelow et al., 1998; Li et al., 2002, Pulleman et al., 2005). Contrarily, Alban and Berry (1994) and Burtelow et al. (1998) found that an earthworm invasion resulted in a $\mathrm{C}$ loss in the upper soil layer. Other fundamental processes for the stabilization of SOM are the leaching of fresh litter compound and of recently formed dissolved organic matter (DOM) from organic layers to mineral soil and the sorption of DOM into mineral surfaces (Sollins et al., 1996; Kaiser and Guggenberger, 2000; Kalbitz and Kaiser, 2008). In case of prolonged leaching, however, the litter can become more resistant to decomposition, as a consequence of the significant loss of soluble organic compounds, and readily degradable (Mangenot et al., 1980).

In this study, the objectives were (i) termining the contribution of litter in soil organic carbon (SOC) sequestration, (ii) analyzing the mechanisms of $\mathrm{C}$ translocation from litter to soil and (iii) singling out the amount of $\mathrm{C}$ leached and the role of earthworms in this process through isotopic analysis.

\section{Material and method}

\subsection{Experimental layout, soil and litter sampling}

The experiment was carried out in the fields of the Department of Agricultural and Forestry Sciences, University of Palermo, Italy $\left(38^{\circ} 06^{\prime} \mathrm{N}, 13^{\circ} 20^{\prime} \mathrm{E}, 50 \mathrm{~m}\right.$ a.s.l.). According to World Reference Base for Soil Resources (WRB, 2006), the soil used was shallow Aric regosol, rich in limestone (46\% of $\mathrm{CaCO}_{3}$ ) with a $\mathrm{pH}$ value of 7.61 , a sandy-clay-silty texture (53.9\% sand, $22.6 \%$ silt and $23.4 \%$ clay) and an organic matter content of $1.40 \%$. The climate was semiarid Mediterranean with a dry period of 4-5 months (mean temperature: minimum $13.7^{\circ} \mathrm{C}$, maximum $22.1^{\circ} \mathrm{C}$; mean annual rainfall: $531 \mathrm{~mm}$ ).

The field plot used in the experiment was a Cynodon meadow. The soil under Cynodon was a $\mathrm{C}_{4}$ soil under isotopic steady state because it had been covered with Cynodon ( $\mathrm{C}_{4}$ photosynthetic pathway plant) for more than 15 years. The $\delta^{13} \mathrm{C}$ of the experimental soil was $-14.5 \pm 1.8$. Cynodon meadow was established with an inter-specific bermuda grass hybrid (C. dactylon x C. transvaalensis), cv Tifway 419.

Agronomic management of the turf grass included monthly application of $50 \mathrm{~kg} \mathrm{ha}^{-1}$ of $\mathrm{N}, 10 \mathrm{~kg} \mathrm{ha}^{-1}$ of $\mathrm{P}$ and $40 \mathrm{~kg} \mathrm{ha}^{-1}$ of $\mathrm{K}$ fertilizer from April to October. Irrigation was carried out during the spring-summer season with a sprinkler system in order to reinstate evapotranspiration (determined by a Class A evaporimeter and rainfall). The turf grass was maintained at a height of $30-35 \mathrm{~mm}$ using a reel lawn mower two to three times a week. The cuttings were removed without grasscycling or mulching.

Plastic cores (n. 30 samples), $20 \mathrm{~cm}$ diameter and $40 \mathrm{~cm}$ height, were installed in the meadow soil after a careful removal of the grasses in March 2013 (Fig. 1). The cores were
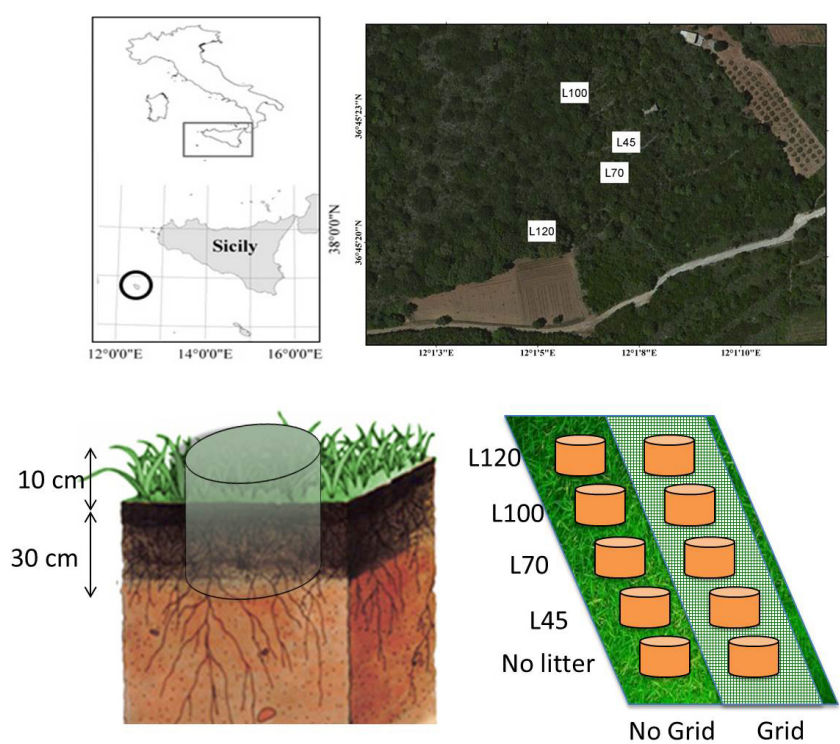

Figure 1. Sampling area of litter in Pantelleria secondary succession (numbers represent litter in field abandoned for 120, 100, 70 and 40 years) and experimental design in meadow field. Numbers indicate the age since abandon.

buried $30 \mathrm{~cm}$, with a $10 \mathrm{~cm}$ surface collar. In 15 of the installed cores, a grid $(0.1 \mathrm{~mm})$ was placed on top of the soil core to avoid the earthworms crossing. Undisturbed different litters (four litters of $\mathrm{C} 3$ plant) were placed on top of soil. In all, 30 cores were placed ( 5 litter treatments ( 4 litters +1 no litter) $\times 2$ grid (grid and no grid) $\times 3$ replicas). Soil samples were collected in February 2014. The $30 \mathrm{~cm}$ soil core was divided in four subsamples (each $7.5 \mathrm{~cm}$ soil thickness). The soil was dried and $2 \mathrm{~mm}$ sieved, and the organic fragments were removed.

Litters were collected with cores $(20 \mathrm{~cm}$ diameter $)$ in four different successional stages of a secondary succession in Pantelleria island, Italy (Sicily, $36^{\circ} 44^{\prime} / 36^{\circ} 50^{\prime} \mathrm{N}$, $\left.11^{\circ} 57^{\prime} / 12^{\circ} 03^{\prime} \mathrm{E}\right)$. The selected stages for litter collection were: maquis 45 years since abandon (L45), maquis 70 years since abandon (L70), maquis 100 years since abandon (L100) and forest 120 years since abandon (L120). The abandonment age of the sampled successional stages was determined by evaluating aerial photographs taken in 1955 and 1968 (produced by Istituto Geografico Militare, Florence) and 1987 (Regione Siciliana) (La Mantia et al., 2008). The sampled areas were located in direct proximity to each other and were characterized by comparable abiotic conditions (aspect, slope, soil type, rock outcrop, stone cover, etc.). The land covers where litters were placed are described in Table 1 .

\subsection{Litter analysis}

Dry biomass weight and its chemical composition (acid detergent lignin (ADL), neutral detergent fibre (NDF), cellu- 
Table 1. Characteristics of litter collected in Pantelleria island.

\begin{tabular}{|c|c|c|c|c|}
\hline $\begin{array}{l}\text { Successional } \\
\text { stages }\end{array}$ & $\begin{array}{l}\text { Years since } \\
\text { abandon }\end{array}$ & Vegetation (Main species) & $\begin{array}{l}\text { Soil use during } \\
\text { the } 20 \text { th century }\end{array}$ & $\begin{array}{l}\text { Current } \\
\text { use }\end{array}$ \\
\hline 1 & 45 & $\begin{array}{l}\text { High maquis (Pistacia lentiscus, Quercus ilex, Phillyrea latifolia, } \\
\text { Calicotome infesta, Erica arborea, Cistus salviifolius) }\end{array}$ & No use after abandon & No use \\
\hline 2 & 70 & Maquis forest (Quercus ilex, Pistacia lentiscus, Phillyrea latifolia) & Coppice & No use \\
\hline 3 & 100 & Forest (Quercus ilex, Pistacia lentiscus) & Coppice & No use \\
\hline 4 & 120 & Forest (Quercus ilex, Smilax aspera) & High forest & No use \\
\hline
\end{tabular}

lose) were determined using Van Soest sequential method for each collected litter (Van Soest et al., 1991).

The litter respiration rates $\left(\mathrm{mg} \mathrm{CO}_{2}\right.$ day $^{-1}$ dry litter) were measured during the incubation experiment using a method of alkali absorption in a closed chamber. Three replicates in each litter treatment with three blank samples were measured. Ten grams of litter were placed inside $1 \mathrm{~L}$ glass bottle. A $30 \mathrm{~mL} 0.1 \mathrm{~N} \mathrm{NaOH}$ solution was used to trap the $\mathrm{CO}_{2}$ which was released inside the bottle. The $\mathrm{CO}_{2}$-trapped solution titrated with $\mathrm{HCl}$ solution using phenolphthalein and methyl-orange as color indicator. During the 7 days of incubation, $\mathrm{CO}_{2}$ measurements were done after $24,48,60$ and $96 \mathrm{~h}$ and 1 week from the start of incubation. All flasks were ventilated for $30 \mathrm{~min}$ with fresh air $24 \mathrm{~h}$ before the $\mathrm{CO}_{2}$ sampling, and an $\mathrm{NaOH}$ trap was placed inside the bottle and then sealed with rubber stoppers. The $\mathrm{C}$ mineralization rate was expressed in mg $\mathrm{CO}_{2}-\mathrm{Cg}^{-1} \mathrm{TOC}$ day $^{-1}$ and was fitted to the following first-order decay function:

Mineralized $\mathrm{C}=\mathrm{C}_{\mathrm{r}} e^{-k t}$,

where $C_{r}$ is the readily mineralizable $C$ at time 0 (i.e., the intercept value), $k$ is the decay rate constant and $t$ is the time. The amount of total $\mathrm{C}$ mineralized was calculated through the linear interpolation of two neighboring measured rates and the numerical integration over time as reported in the following equation:

$\mathrm{CO}_{2}-\mathrm{C}=\sum_{i}^{n}\left[\left(r_{i}+r_{i+1}\right) \cdot \frac{d}{2}\right]+\ldots+\left[\left(r_{n-i}+r_{n}\right) \cdot \frac{d}{2}\right]$,

where $i$ is the date of the first measurement of $\mathrm{CO}_{2}-\mathrm{C}$ rate, $n$ is the date of the last measurement of $\mathrm{CO}_{2}-\mathrm{C}$ rate, $r$ is the $\mathrm{CO}_{2}-\mathrm{C}$ rate expressed as $\mathrm{mg} \mathrm{CO}_{2}-\mathrm{C} \mathrm{kg}^{-1}$ dry soil and $d$ is the number of days between the two consecutive $\mathrm{CO}_{2}$ rate measurements.

The mean residence time (MRT) in days was determined as a reciprocal of the rate constant $(k)$ of first-order decay (Eq. 1).

\subsection{Chemical analysis}

For each soil sample the $\mathrm{C}$ content and $\delta^{13} \mathrm{C}$ abundance were measured. The $\delta^{13} \mathrm{C}$ isotopic signature of litter biomass was also analyzed. For SOC and the $\delta^{13} \mathrm{C}$ analysis, an elemental analyzer isotope ratio mass spectrometer was used. The reference material used for analysis was IA-R001 (Iso-Analytical Limited standard wheat flour, $\delta^{13} \mathrm{CV}-\mathrm{PDB}=-26.43 \%$ ) . IA-R001 is traceable to IAEA-CH-6 (cane sugar, $\delta^{13} \mathrm{CV}$ $\mathrm{PDB}=-10.43 \%$ ). IA-R001, IA-R005 (Iso-Analytical Limited standard beet sugar, $\delta^{13} \mathrm{CV}-\mathrm{PDB}=-26.03 \%$ ) and IAR006 (Iso-Analytical Limited standard cane sugar, $\delta^{13} \mathrm{CV}$ $\mathrm{PDB}=-11.64 \%$ ) were used as quality control samples for the analysis. The International Atomic Energy Agency (IAEA), Vienna, distribute IAEA-CH-6 as a standard reference material.

The results of the isotope analysis are expressed as a $\delta$ value $(\% o)$ relative to the international Pee Dee Belemnite standard as follows:

$\delta(\% o)=\frac{R_{\mathrm{s}}-R_{\mathrm{st}}}{R_{\mathrm{st}}} \cdot 1000$,

where $\delta=\delta{ }^{13} \mathrm{C}, R={ }^{13} \mathrm{C} /{ }^{12} \mathrm{C}, \mathrm{s}=$ sample and $\mathrm{st}=$ standard.

\subsection{Data calculation}

Natural abundance of $\delta^{13} \mathrm{C}$ was used to determine the proportion of $\mathrm{C}$ in SOC derived from the new $\mathrm{C}$ input $\left(\mathrm{C}_{3}-\mathrm{C}\right)$. These proportions were calculated with the mixing equation (Gearing, 1991) separately for grid and no grid plots:

New carbon derived $=f(\mathrm{NCD})(\%)=\frac{\left(\delta^{13} \mathrm{C}_{\text {new }}-\delta^{13} \mathrm{C}_{\text {old }}\right)}{\left(\delta^{13} \mathrm{C}_{\text {litter }}-\delta^{13} \mathrm{C}_{\text {old }}\right)}$,

where NCD is the fraction of new $\mathrm{C}$ derived, $\delta^{13} \mathrm{C}_{\text {new }}$ is the isotope ratio of the soil sample, $\delta^{13} \mathrm{C}_{\text {litter }}$ is the isotope ratio of different litters and $\delta^{13} \mathrm{C}_{\text {old }}$ is the isotopic ratio of the previous vegetation (Cynodon).

Carbon derived from worms was calculated as the difference between NCD in grid and no grid treatments.

The mass of new carbon additions was calculated according to Eq. (5).

New carbon $\left(\mathrm{g} \mathrm{kg}^{-1}\right)=$

$\mathrm{C}_{\text {soil }}\left(\mathrm{g} \mathrm{kg}^{-1}\right) \cdot(1-$ new carbon derived $)$

The standard deviation of the $\delta^{13} \mathrm{C}$ and $\mathrm{C}$ values were calculated for each depth and treatment. For the average value, the Duncan test was used at $p<0.05$ (SAS Institute, 2001). 
Table 2. Biomass composition (\% of dry biomass) of litters in different stages of secondary succession (L45, L70, L100 and L120). Abbreviations: $\mathrm{ADF}=$ acid detergent fibre, $\mathrm{NDF}=$ neutral detergent fibre, $\mathrm{C}$ min $=$ readily mineralizable carbon, $\mathrm{MRT}=$ mean residence time. $\mathrm{In}$ the same column, different letters indicate differences for $P \leq 0.05$.

\begin{tabular}{lllllll}
\hline Litter & C min $\left(\mathrm{mg} \mathrm{kg}^{-1}\right)$ & MRT days & $R^{2}$ & Cellulose & ADL & NDF \\
\hline L45 & $154.1 \mathrm{c}$ & $25.0 \mathrm{a}$ & 0.92 & 19.0 & $28.9 \mathrm{~b}$ & $44.6 \mathrm{~b}$ \\
L70 & $163.2 \mathrm{c}$ & $26.0 \mathrm{a}$ & 0.86 & 17.6 & $24.1 \mathrm{c}$ & $39.3 \mathrm{c}$ \\
L100 & $150.7 \mathrm{~b}$ & $26.0 \mathrm{a}$ & 0.90 & 18.2 & $30.5 \mathrm{a}$ & $44.4 \mathrm{~b}$ \\
L120 & $217.0 \mathrm{a}$ & $22.0 \mathrm{~b}$ & 0.92 & 19.9 & $31.4 \mathrm{a}$ & $51.4 \mathrm{a}$ \\
\hline
\end{tabular}

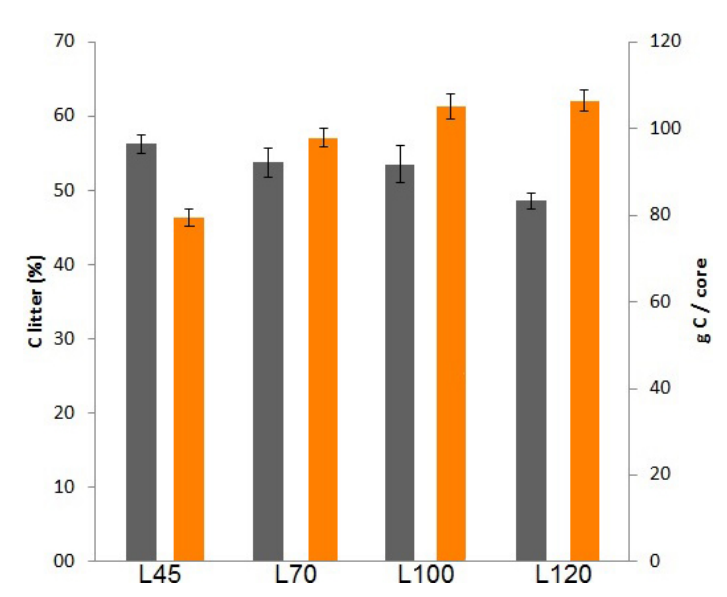

Figure 2. C litter content (\%) (grey columns) and C litter input (g) for each core (orange columns) in L45, L70, L100 and L120 treatments.

\section{Results}

\subsection{Litter characteristics}

The plant litter collected during the stages of secondary succession differed in the total weight and $\mathrm{C}$ content. The highest weight of litter biomass was in L120 with values of $1113 \pm 90 \mathrm{~g} \mathrm{~m}^{-2}$, followed by L100, L45 and L70 with values of $1027 \pm 77,915 \pm 104$ and $946 \pm 82 \mathrm{~g} \mathrm{~m}^{-2}$, respectively. The highest $\mathrm{C}$ content of litter was in L45 and decreased with the increase of the age of abandon (Fig. 2); however, L120 contributed with the highest $\mathrm{C}$ litter input (total $\mathrm{C}$ litter/core) due to the higher weight in comparison to other litters of the stages of secondary succession.

The results of litter incubation experiment showed the lowest cumulative $\mathrm{CO}_{2}$ emission for $\mathrm{L} 45$ and $\mathrm{L} 100\left(32 \mathrm{mg} \mathrm{CO}_{2}\right.$ $\left.\mathrm{Cg}^{-1}\right)$, followed by $\mathrm{L} 70\left(35 \mathrm{mg} \mathrm{CO}_{2}-\mathrm{Cg}^{-1}\right)$ and $\mathrm{L} 120$ (40 mg CO $2-\mathrm{Cg}^{-1}$ ).

The MRT was not significantly different among litter ages, except for L120 (Table 2). These findings were confirmed by the readily mineralizable $\mathrm{C}$ which was highest in L120 (Table 2). The composition of litter was not statistically different among successional stages regarding cellulose and ADL content (Table 2). The NDF value was, instead, significantly higher in L120 in comparison to litters of other successional stages.

\subsection{Soil carbon content and distribution}

The total amount of SOC differed under the two treatments (grid and no grid) and time of abandon. The SOC was significantly higher in soils where L120 was placed on the top of soil cores, followed by the other litter treatments (Table 3). Comparison between grid and no grid treatments showed the highest $\mathrm{C}$ content in soil cores without grid for all litters.

After 1 year of litter permanence, the SOC under L120 increased on average $(0-30 \mathrm{~cm})$ by 26 and $40 \%$ in grid and no grid treatment, respectively, in comparison to the no litter treatment.

Such C increase was smaller in grid treatment for the other litters (L45, L70 and L100) with a value of about $12 \%$. In the no grid treatment, the SOC increased by 22,23 and $15 \%$ in soil under L100, L70 and L45, respectively, in comparison to the no litter treatment. SOC decreased with the increase of the soil depth, but on average the difference between the first and the deepest soil layer was more pronounced in the no grid treatment (Table 3).

\section{3 ${ }^{13} \mathrm{C}$ isotopic signature in soil profile}

The value of soil $\delta^{13} \mathrm{C}$ changed significantly after litter positioning (Fig. 3). The baseline is represented by soil without litter, where the $\delta^{13} \mathrm{C}$ values were $-14.0 \pm 0.3$ and $-16.0 \pm$ $0.4 \%$ in the top and deepest soil layer, respectively. After litter position, $\delta^{13} \mathrm{C}$ was depleted due to $\mathrm{C}_{3}$ litter input. The most depleted soil was L120 with average (grid and no grid treatment) values of -18.6 and $-21.6 \%$ in the top and deepest soil layer, respectively (Fig. 3). For the others litter treatments the value ranged between -15.0 and $-20.5 \%$.

The effect of litter input on $\mathrm{C}$ stock was highlighted by estimates of $\mathrm{C}$ derived from litter $\left(\mathrm{C}_{3}\right.$ plant) in the meadow soil $\left(\mathrm{C}_{4}\right.$ soil). After 1 year of litter permanence, $\mathrm{C}$ originated from litter input was 32.4, 34.2, 38.5 and $49.8 \%$ of total SOC in L45, L70, L100 and L120, respectively.

The new derived soil $\mathrm{C}\left(\mathrm{C}_{3}\right.$-SOC) was lower for all litter treatments in soil with grid. The portion of $\mathrm{C}_{3}-\mathrm{C}$ in soil with grid was, in fact, 12.4, 23.1, 23.4 and $40.7 \%$ of total $\mathrm{C}$ in L45, L70, L100 and L120, respectively (Fig. 4). Considering 
Table 3. Average of soil organic carbon (\%) at different soil depths. For each treatment different letters indicate differences for $P \leq 0.05$.

\begin{tabular}{lccccc|ccccccc}
\hline & \multicolumn{7}{c}{ Grid } & \multicolumn{7}{c}{ No grid } & \\
\cline { 2 - 10 } $\begin{array}{l}\text { Soil depth } \\
(\mathrm{cm})\end{array}$ & No litter & L45 & L70 & L100 & L120 & No litter & L45 & L70 & L100 & $\begin{array}{c}\text { L120 } \\
\begin{array}{c}\text { Grid } \\
\text { average }\end{array}\end{array} \begin{array}{c}\text { No grid } \\
\text { average }\end{array}$ \\
\hline $0-7.5$ & 1.5 & 1.8 & 1.8 & 1.8 & 1.9 & 1.6 & 1.9 & 1.8 & 2.0 & 2.4 & $1.8 \mathrm{a}$ & $1.9 \mathrm{a}$ \\
$7.5-15$ & 1.4 & 1.5 & 1.6 & 1.5 & 1.7 & 1.4 & 1.9 & 1.9 & 2.0 & 2.1 & $1.5 \mathrm{~b}$ & $1.9 \mathrm{a}$ \\
$15-22.5$ & 1.3 & 1.6 & 1.3 & 1.4 & 1.6 & 1.3 & 1.6 & 2.1 & 1.6 & 1.7 & $1.4 \mathrm{~b}$ & $1.7 \mathrm{a}$ \\
$22.5-30$ & 1.2 & 1.1 & 1.3 & 1.2 & 1.5 & 1.2 & 0.9 & 0.9 & 1.1 & 1.4 & $1.3 \mathrm{~b}$ & $1.1 \mathrm{~b}$ \\
\hline Average & $1.3 \mathrm{~d}$ & $1.5 \mathrm{c}$ & $1.5 \mathrm{c}$ & $1.5 \mathrm{c}$ & $1.7 \mathrm{~b}$ & $1.4 \mathrm{a}$ & $1.6 \mathrm{c}$ & $1.7 \mathrm{~b}$ & $1.7 \mathrm{~b}$ & $1.9 \mathrm{a}$ & & \\
\hline
\end{tabular}

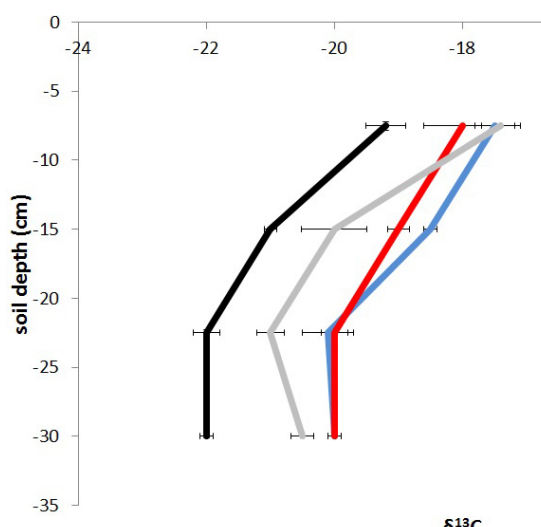

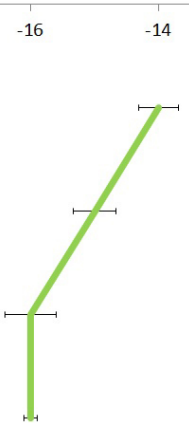

\footnotetext{
$\delta^{13} \mathrm{C}$
}

Figure 3. $\delta^{13} \mathrm{C}$ value at different depth in no grid (a) and grid (b) treatment. The green line represents no litter treatment, while blue, red, grey and black represent litter in fields abandoned for 120, 100, 70 and 40 years, respectively.

only the $\mathrm{C}_{3}-\mathrm{C}$ of SOC for each litter treatment, the contribution of earthworms to the incorporation of new $\mathrm{C}_{3}-\mathrm{SOC}$ was in percentage higher in L45, decreased with the age of litter and decreased for each treatment with the increase of the soil depth. The difference of $\mathrm{C}_{3}-\mathrm{C}$ between no grid, grid treatment and depth assesses the earthworm contribution to soil $\mathrm{C}$ increase and distribution.

\section{Discussion}

\subsection{Litter contribution to SOC stock}

Previous studies on the island of Pantelleria demonstrated the potential of land cover in the change of C stocks (Novara et al., 2014; Saiano et al., 2013). In fact, land abandonment determines the increase in litter layer and SOC. In natural ecosystems, unlike ecosystems on arable lands, litter is not incorporated into the soil. For this reason it was hypothesized that SOC increase is due to $\mathrm{C}$ leaching and/or to earthworm contribution. This hypothesis was confirmed by the present experiment, in which the effect of plant litter contribution to SOC stock was isolated from other soil and environmental parameters. In line with several reports in other ecosystems (Lal, 2005; Yu and Jia, 2014), we recorded that the SOC stock depends on C litter input as well as on litter qual- ity. The incubation experiment of litters showed differences in readily mineralizable $\mathrm{C}$, litter composition (NDF \%) and consequently $\mathrm{C}$ litter mineralization rate. The litter of L120 had a higher amount of readily mineralizable $\mathrm{C}$ in comparison to other litters, and it was easily decomposed and transferred to SOC pool. The faster mineralization rate of L120 could be attributed both to a different composition of plant species (lower content of sclerophyll) (Gianguzzi, 1999) and to a variation in the micro-climatic conditions (Wang et al., 2010; Sheffer et al., 2015) due to a higher accumulation layer on the soil surface. As far as the effect of plant species on the litter mineralization rate is concerned, several studies found a lower litter decomposition rate in $Q$. ilex in comparison to other Mediterranean species, like Myrtus and Cistus (Berg at al., 1996; Fioretto et al., 2005). Likewise, Maisto et al. (2011) found a slower decomposition of $Q$. ilex in comparison to $P h$. angustifolia, while no significant difference in the decomposition rate was recorded between $Q$. ilex and Pistacia lentiscus. In these studies the lower decomposition of $Q$. ilex was attributed to higher lignin content. Our results confirm those of other research with regard to the higher lignin content of $Q$. ilex, but this was not closely associated to lower decomposition rates. In fact, L120, where the main species was Q. ilex, was the litter with a higher decomposition rate. Therefore, other aspects could explain the differences in the 
L45

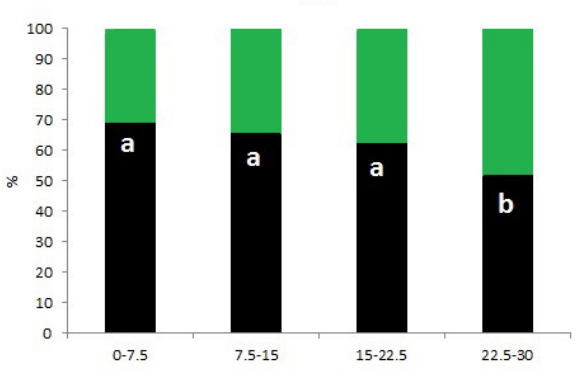

L100

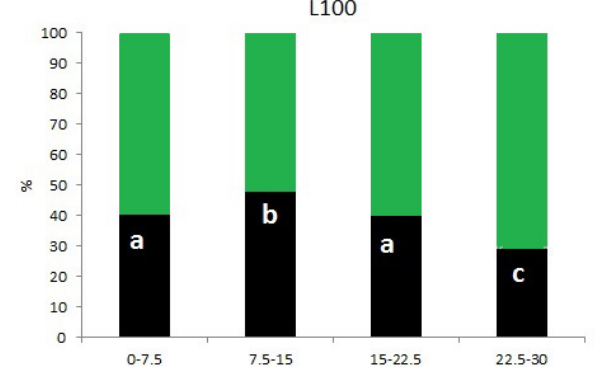

L70

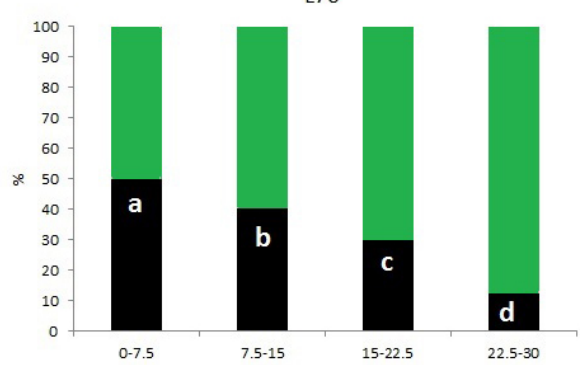

L120

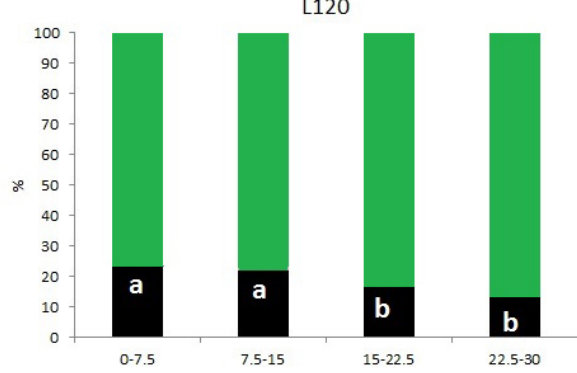

Figure 4. Contribution (\%) of worm activity (black columns) and DOC (green columns) in $\mathrm{C}_{3}-\mathrm{C}$ portion at different soil depth. For each portion, different letters indicate differences for $P \leq 0.05$.

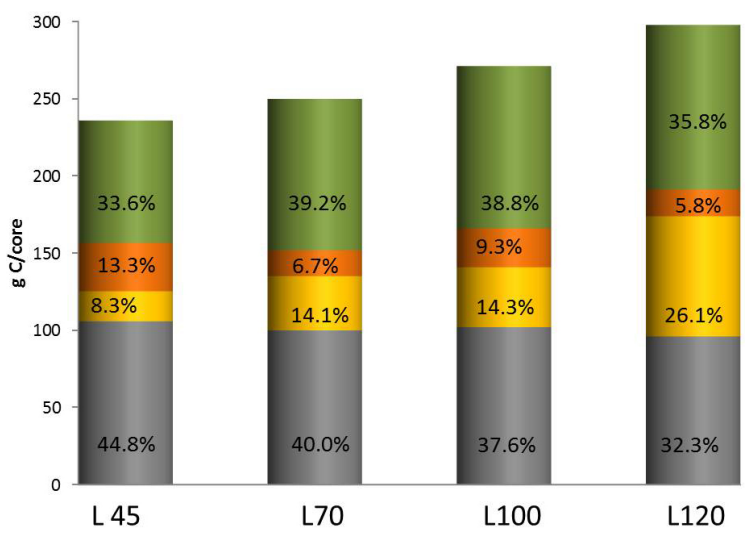

Figure 5. C content in each core (L45, L70, L100 and L120) originated from $\mathrm{C} 4-\mathrm{SOC}$ (grey columns), $\mathrm{C}_{3}$-SOC from worm activity (yellow columns), $\mathrm{C}_{3}$-SOC from DOC leaching (orange columns) and $\mathrm{C}$ litter (green columns).

decomposition rates, like the percentage of a species in each stage of succession, the age of litter and the thickness of litter.

\subsection{Influence of earthworm on soil carbon}

Plant litter is the main source of SOM in soils under secondary succession. The transformation of C litter into SOM is caused by the decomposition of plant biomass and its incorporation into the soil profile. Responsible for this mechanisms are bacteria and fungi, forming up to $90 \%$ of the soil microbial biomass (Dix and Webster, 1995; Schimel et al., 1999) and faunal groups. Our observations highlighted the annual contribution to SOM derived from litter and singled out the activity of decomposition through the difference of isotopic signature between previous SOC-C $\left(\mathrm{C}_{4}\right.$ soil $)$ and the new $\mathrm{C}_{3}-\mathrm{C}$ input originated from litter. The ${ }^{13} \mathrm{C}$ litter recovery in the soil profile was higher in L120 (89\%), followed by L45 (63\%), L100 (60\%) and L70 (52\%). Firstly, the activity of microbial biomass in soil samples where the grid was placed between litter and soil was highlighted. In this case, the new $\mathrm{C}_{3}-\mathrm{C}$ represented the $\mathrm{C}$-pool originated by fungi and bacterial decomposition, transferred into the soil depth mainly through dissolved organic carbon. Such decomposition and incorporation activity contributed to $\mathrm{C}$ increase up to $77.6 \mathrm{~g} \mathrm{core}^{-1}$ year $^{-1}$ in L120 treatment (Fig. 5). However, the difference between soil core with and without litter gave information about the contribution of earthworms to litter decomposition and incorporation into the soil. In several studies, the introduction of earthworms in cold temperate forests resulted in a decline of SOC (Bohlen et al., 2004; Alban and Berry, 1994). The results of the present study instead suggest that earthworms have the potential to increase SOC. After 1 year, earthworm activity increased SOC by 13.5, 11.3, 11.1 and 5\%, in L120, L100, L70 and L45, respectively. The effects of earthworm activity on the recovery of soil C released from litter could be attributed to different mechanisms: (i) the mixture of undecayed particulate $\mathrm{C}$ into the soil, (ii) the creation of preferential flow paths in the soil increasing nutrient transportation and (iii) protection of $\mathrm{C}$ in soil aggregates cre- 
ated by earthworm feeding (Bohlen et al., 2004; Fahey et al., 2013; Fonte et al., 2007).

\section{Conclusions}

This study highlights the effects of vegetation succession on $\mathrm{C}$ dynamics in soil after the termination of its agricultural use. Based on $\delta^{13} \mathrm{C}$ signature of $\mathrm{C}_{3}-\mathrm{C}$ of litter and $\mathrm{C}_{4}-\mathrm{C}$ of meadow soil, the annual contribution of vegetation input to $\mathrm{C}$ stock was estimated. Moreover, the effect of DOC leaching and earthworm activities on $\mathrm{C}$ storage in soil depth have also been evaluated.

Hence in order to understand the ecosystem processes of $\mathrm{C}$ sequestration in semiarid environments, a better understanding of the impact of above-ground biomass on soil community is still needed.

Acknowledgements. This research was financially supported by the MIUR through the PRIN "CARBOTREES" project.

Edited by: A. Cerdà

\section{References}

Alban, D. H. and Berry, E. C.: Effects of earthworm invasion on morphology, carbon, and nitrogen of a forest soil, Appl. Soil Ecol., 1, 243-249, 1994.

Berg, B., Ekbohm, G., Johansson, M. B., McClaugherty, C., Rutigliano, F. A., and Virzo de Santo, A.: Maximum decomposition limits of forest litter types: a synthesis, Can. J. Bot., 74, 659-672, 1996.

Bohlen, P. J., Pelletier, D. M., Groffman, P. M., Fahey, T. J., and Fisk, M. C.: Influence of earthworm invasion on redistribution and retention of soil carbon and nitrogen in northern temperate forests, Ecosystems, 7, 13-27, 2004.

Burtelow, A. E., Bohlen, P. J., and Groffman, P. M.: Influence of exotic earthworm invasion on soil organic matter, microbial biomass and denitrification potential in forest soils of the northeastern United States, Appl. Soil Ecol., 9, 197-202, 1998.

Costa, G. and La Mantia, T.: Il ruolo della macchia mediterranea nello stoccaggio del carbonio atmosferico, Forest, 2, 378-387, 2005.

Dix, N. J. and Webster, J.: Fungal Ecology, Chapman and Hall, London, 549 pp., 1995.

Edwards, C. A. and Bohlen, P. J.: The Biology and Ecology of Earthworms, Chapman and Hall, London, UK, 1996.

Fahey, T. J., Yavitt, J. B., Sherman, R. E., Maerz, J. C., Groffman, P. M., Fisk, M. C., and Bohlen, P.: Earthworm effects on the conversion of litter $\mathrm{C}$ and $\mathrm{N}$ into soil organic matter in a sugar maple forest, Ecol. Appl., 23, 1185-1201, 2013.

Fioretto, A., Musacchio, A., Andolfi, G., and Virzo De Santo, A.: Decomposition dynamics of litters of various pine species in a Corsican pine forest, Soil Biol. Biochem., 30, 721-727, 1998.

Fioretto, A., Di Nardo, C., Papa, S., and Fuggi, A.: Lignin and cellulose degradation and nitrogen dynamics during decomposition of three leaf litter species in a Mediterranean ecosystem., Soil Biol. Biochem., 37, 1083-1091, 2005.

Fonte, S. J., Kong, A. Y. Y., van Kessel, C., Hendrix, P. F., and Six, J.: Influence of earthworm activity on aggregate-associated carbon and nitrogen dynamics differs with agroecosystem management, Soil. Biol. Biochem, 39, 1014-1022, 2007.

Gearing, J. N.: The study of diet and trophic relationships through natural abundance ${ }^{13} \mathrm{C}$, in: Carbon Isotope Techniques, edited by: Coleman, D. C. and Fry, B., Academic Press, San Diego, 201-218, 1991.

Gianguzzi, L.: Vegetazione e bioclimatologia dell'isola di Pantelleria (Canale di Sicilia), Braun-Blanquetia, 22, 1-70, 1999.

Kaiser, K. and Guggenberger, G.: The role of DOM sorption to mineral surfaces in the preservation of organic matter in soils, Org. Geochem., 31, 711-725, 2000.

Kalbitz, K. and Kaiser, K.: Contribution of dissolved organic matter to carbon storage in forest mineral soils, J. Plant Nutr. Soil Sc., 171, 52-60, 2008.

La Mantia, T., Rühl, J., Pasta, S., Campisi, D., and Terrazzino, G.: Structural analysis of woody species in Mediterranean old fields, Plant Biosyst., 142, 462-471, 2008.

Lal, R.: Forest soils and carbon sequestration, Forest Ecol. Manag., 220, 242-258, 2005.

Lee, K. E.: Earthworms: Their Ecology and Relationships with Soils and Land Use, Academic Press, New York, 333-349, 1985.

Li, D., Zhu, H., Liu, K., Liu, X., Leggewie, G., Udvardi, M., and Wang, D.: Purple acid phosphatases of Arabidopsis thaliana, Comparative analysis and differential regulation by phosphate deprivation, J. Biol. Chem., 227, 27772-27781, 2002.

Maisto, G., De Marco, A., Meola, A., Sessa, L., and Virzo De Santo, A.: Nutrient dynamics in litter mixtures of four Mediterranean maquis species decomposing in situ, Soil Biol. Biochem., 43, 520-530, 2011.

Mangenot, F., Toutain, F., and Pesson, P. (Eds.): Les Litieres Forestieres et Leur Evolution, Actualites d' Ecologie Forestiere: Sol, Flore, Faune, Gauthier-Villar, Paris, 3-59, 1980.

Novara, A., La Mantia, T., Ruhl, J., Badalucco, L., Kuzyakov, Y., Gristina, L., and Laudicina, V. A.: Dynamics of soil organic carbon pools after agricultural abandonment, Geoderma, 235-236, 191-198, 2014.

Parras-Alcántara, L., Lozano-García, B., and Galán-Espejo, A.: Soil organic carbon along an altitudinal gradient in the Despeñaperros Natural Park, southern Spain, Solid Earth, 6, 125134, doi:10.5194/se-6-125-2015, 2015.

Peng, F., Quangang, Y., Xue, X., Guo, J., and Wang, T.: Effects of rodent-induced land degradation on ecosystem carbon fluxes in an alpine meadow in the Qinghai-Tibet Plateau, China, Solid Earth, 6, 303-310, doi:10.5194/se-6-303-2015, 2015.

Pulleman, M. M., Six, J., Uyl, A., Marinissen, J. C. Y., and Jongmans, A. G.: Earthworms and management affect organic matter incorporation and microaggregate formation in agricultural soils, Appl. Soil Ecol., 29, 1-15, 2005.

Saiano, F., Oddo, G., Scalenghe, R., La Mantia, T., and AjmoneMarsan, F.: DRIFTS Sensor: Soil Carbon Validation at Large Scale (Pantelleria, Italy), Sensors, 13, 5603-5613, 2013.

SAS Institute: SAS/STAT User's Guide for Personal Computers, Release 8.01, SAS Institute, Cary, NC, USA, 2001.

Sayer, E. J., Powers, J. S., and Tanner, E. V. J.: Increased litterfall in tropical forests boosts the transfer of soil $\mathrm{CO}_{2}$ to the atmosphere, 
PLOS ONE, 12, e1299, doi:10.1371/journal.pone.0001299, 2007.

Schimel, J. P., Gulledge, J. M., Clein-Curley, J. S., Lindstrom, J. E., and Braddock, J. F.: Moisture effects on microbial activity and community structure in decomposing birch litter in the Alaskan taiga, Soil Biol. Biochem., 31, 831-838, 1999.

Sheffer, E., Canham, C. D., Kigel, J., and Perevolotsky, A.: Countervailing effects on pine and oak leaf litter decomposition in human-altered Mediterranean ecosystems, Oecologia, 177, 1039-1051, doi:10.1007/s00442-015-3228-3, 2015.

Smith, P.: Land use change and soil organic carbon dynamics, Nutr. Cycl. Agroecosys., 81, 169-178, 2008.

Smolander, A., Levula, T., and Kitunen, V.: Response of litter decomposition and soil $\mathrm{C}$ and $\mathrm{N}$ transformations in a Norway spruce thinning stand to removal of logging residue, Forest Ecol. Manag., 256, 1080-1086, 2008.

Sollins, P., Homann, P., and Caldwell, B. A.: Stabilization and destabilization of soil organic matter: mechanisms and controls, Geoderma, 74, 65-105, 1996.

Swift, M. J., Heal, O. W., and Anderson, J. M.: University of California Press: Decomposition in Terrestrial Ecosystems, Berkeley, 5, 167-219, 1979.
Tiunov, A. V., Bonkowski, M., Alphei, J., and Scheu, S.: Microflora, protozoa and nematoda in lumbricus terrestris burrow walls: a laboratory experiment, Pedobiologia, 45, 46-60, 2001.

Van Soest, P. J., Robertson, J. B., and Lewis, B. A.: Methods for dietary fiber, neutral detergent fiber, and nonstarch polysaccharides in relation to animal nutrition, J. Dairy Sci., 74, 3583-3597, 1991.

Wang, S., Ruan, H., and Han, Y.: Effects of microclimate, litter type, and mesh size on leaf litter decomposition along an elevation gradient in the Wuyi Mountains, China. Ecol Res., 25, 11131120, doi:10.1007/s11284-010-0736-9, 2010.

WRB: World Reference Base for Soil Resources 2006, first update 2007, World Soil Resources Reports No. 103, FAO, Rome, 2006.

Wurst, S., Dugessa-Gobena, D., Langel, R., Bonkowski, M., and Scheu, S.: Combined effects of earthworms and vesiculararbuscular mycorrhizas on plant and aphid performance, New Phytol., 163, 169-176, 2004.

Yu, Y. and Jia, Z. Q.: Changes in soil organic carbon and nitrogen capacities of Salix cheilophila Schneid along a revegetation chronosequence in semi-arid degraded sandy land of the Gonghe Basin, Tibet Plateau, Solid Earth, 5, 1045-1054, doi:10.5194/se5-1045-2014, 2014. 